\title{
Phytotoxicity Assessment of Compost-Type Biofertilizer using Co-Composting and Post Composting Fortification Methods
}

\author{
Damilare A. Adetunji ${ }^{*}$, Oluwaseun A. Obideyi ${ }^{2}$, Omolola T. Evinemi, Olusegun A. Adetunji ${ }^{4}$ \\ ${ }^{1}$ Bioresources Development Centre, Ilorin Kwara State, \\ Ibadan, Nigeria \\ ${ }^{2}$ Department of medical biotechnology, National Biotechnlogy Development Agency, Abuja, FCT. \\ Abuja, Nigeria \\ ${ }^{3}$ Bioresources Development Centre Ogbomoso Oyo State. \\ Ogbomoso, Nigeria \\ ${ }^{4}$ Bioresources Development Centre Ilorin, Kwara State. \\ Abuja, Nigeria \\ *Corresponding author's email: adetunjioluwadami [AT] gmail.com
}

\begin{abstract}
Phytotoxicity sets in when immature and not well prepared compost is used on the farm. This research work was targeted at preparing compost from different organic material combination and assessing the phytotoxic effects of different compost combinations. Compost of organic materials was prepared and fortified giving the following combinations: $P M+R B+B M+G L, P M+S D+B M+G L, P M+R B+G L$ and $P M+S D+G L$. The carbon and nitrogen sources were combined using 1:3 ratio, the combination was sprinkled with water. Data such as ambient temperature of each pile was taken daily, while $\mathrm{pH}$ and electrical conductivity tests were taken on samples fortnightly. On maturation of the compost, post fortification technique was carried out hereby creating two more combinations tagged PM+RB+GL (BMP) and PM+SD+GL (BMP). The six compost combinations were tested in terms of their germination percentage, after which data on germination \%, relative germination \%, root length, weight gained and germination index were taken and analyzed using anova, their mean were separated using Duncan Multiple Range Test (DMRT) at $5 \%$ probability level.

Fortification with phosphorus source at the onset of composting promoted plant growth hence no sign of phytotoxicity while fortification with phosphorus source after maturation increased phytotoxicity. $(S D=S a w d u s t, R B$ $=$ Rice bran, $G L=$ Glyricidia sepium and $B M=$ Bone meal).
\end{abstract}

Keywords --- Ambient, Germination index, Maturation, Phytotoxicity, Temperature

\section{INTRODUCTION}

Compost-type Biofertilizer is the product resulting from the controlled biological decomposition of organic material; which is added to the soil with the sole aim of enhancing plant growth and improving soil structure. It is one of nature's best mulches and soil amendments, and can be used instead of chemical fertilizers. Best of all, it is relatively cheap and can be made without spending a cent.

Phytotoxicity is the delay of seed germination, inhibition of plant growth or any adverse effect on plants caused by specific substances (phytotoxins) or growing conditions. The term for plant damage is "phytotoxicity" and it can also be caused by pesticides, nutrients, or physical and environmental damage (wind, sun, hail, etc.). Phytotoxicity appears in several ways on plants, but probably 5 types of damage most commonly occurs which are burn, necrosis, chlorosis, leaf distortion and stunting (Michelle, 2012). Burn is a type of damage that may appear on the tip, the margin, as spots on the leaf or the entire leaf surface may appear burned. The growing tip or bud may also be killed. Necrosis (or death of the plant tissue) is Similar to burn and affecting plants in the same manner. Chlorosis (a yellowing or bleaching effect) also may appear as spots, tip yellowing, or as a general chlorosis of the entire leaf. Leaf distortion mostly appears as curling, 
crinkling, or cupping of the leaf. Stunting is a form of abnormal growth in plants, (Ornamentals northwest archives, 2001). Phytotoxicity very commonly produces a combination of two or more of the five symptoms.

Phytotoxicity of compost is often best evaluated by conducting germination or growth tests (Brewer and Sullivan, 2003), but the test plants have to be chosen with care. Germination Index (GI) is the best way to test the phytotoxicity of compost to plant growth because the results of it are quite straightforward and reliable. The germination index is a maturity test based on seed germination and initial plant growth using a liquid extract from the compost (Zucconi, et al., 1981). It reflects the phytotoxicity of the compost extracts at different stages of composting. The compost is considered mature when the germination index is higher than $60 \%$, compared to the control with distilled water (Zucconi and De Bertoldi, 1987).

\section{MATERIALS AND METHODS}

\subsection{Experimental Site Preparation}

Compost shed was used for the experiment. The shed was cleared of all forms of debris, windows and doors were covered with sac in order to minimize the influence of external factors such as rain droplets and also to maintain an ambient temperature.

\subsubsection{Compost Preparation and Fortification}

Sawdust (SD) and Rice bran (RB) were mixed separately with Poultry Manure (PM) using 1:3 ratio (60g of carbon source: $180 \mathrm{~g}$ of nitrogen source). Each pile was turned every three days for the first two weeks of composting and subsequently at five days interval till the compost matured (after 84 days). The phosphorus source that was added to fortify was bonemeal (BM).

2.1.1.1. Co-Composting Fortification technique: The compost was fortified at the onset of composting giving the following combination PM+SD+BM+GL. Weight of a pile = 255g, PM (180g), SD (60g), BM (7.5g), GL (7.5g). Another combination was formed using RB as carbon source; PM+RB+BM+GL.

2.1.1.2. Post Composting Fortification technique: The compost was fortified with the phosphorus fortifier after maturation. Therefore another combination that is void of the phosphorus fortifier was prepared (PM+SD+GL and $\mathrm{PM}+\mathrm{RB}+\mathrm{GL})$.

To encourage heat buildup and prevent external factors, thick nylon was used to cover the pile and was also used at the base. During the pile turning, adequate water was sprinkled on any pile that is getting dry to preserve moisture content.

\subsection{Data Collection}

The compost combinations were assumed to be stabilized and cured after 84 days using visual appraisal (compost looked like a rich loamy soil) and pile temperature tending towards ambient. Samples were taken for germination test with the aim of getting the germination percentage, root elongation percentage and the germination index. Compost combinations PM+SD+GL and PM+SD+GL were fortified after maturation by adding $1 \mathrm{~g}$ of phosphorus fortifier $(\mathrm{BM})$ to $4 \mathrm{~g}$ of samples taken from the aforementioned combinations. Therefore we have the following combinations altogether $\mathrm{PM}+\mathrm{SD}+\mathrm{GL}+\mathrm{BM}, \mathrm{PM}+\mathrm{RB}+\mathrm{GL}+\mathrm{BM}, \mathrm{PM}+\mathrm{SD}+\mathrm{GL}, \mathrm{PM}+\mathrm{RB}+\mathrm{GL}, \mathrm{PM}+\mathrm{SD}+\mathrm{GL}$ (BMP) and $\mathrm{PM}+\mathrm{RB}+\mathrm{GL}(\mathrm{BMP})$.

Samples $(5 \mathrm{~g})$ were taken from the 6 compost combinations and were poured inside a $120 \mathrm{ml}$ bottle; $50 \mathrm{ml}$ of water was also added to form a mixture. The mixture was agitated uniformly for an hour and was filtered into a clean $120 \mathrm{ml}$ bottle to get a filtrate of the compost combinations (compost tea).

To prepare the growth media for the germination test, $0.8 \mathrm{~g}$ of cotton wool was placed inside a petri dish. Maize seeds were used for the germination test; seeds with good viability percentage were selected and disinfected using $70 \%$ ethanol. For the control experiment, $10 \mathrm{ml}$ of distilled water was sprinkled on the cotton wool inside the petri dishes and the seeds were carefully placed, the petri dishes were covered and edges were sealed with foil (sealing with foil paper was done to regulate the effects of exogenous factors and also to prevent water loss thereby retaining oxygen). For the 6 compost combinations, the prepared compost teas were used instead of distilled water and the above process was repeated for 100\% compost tea concentration and 50\% compost tea concentration. All samples were replicated once. 
Petri dishes were kept in a cool dry place throughout the experiment and after 4 days, data in terms of number of germinated seeds $(\%)$, root elongation $(\mathrm{cm})$ and weight $(\mathrm{g})$ gained by the root was taken. Germination index was calculated to determine compost phytotoxicity.

$$
\begin{aligned}
& \mathrm{G} . \mathrm{I}=\underline{\mathrm{R} . \mathrm{G} \% \times \mathrm{RRL} \%} \\
& 100
\end{aligned}
$$

\begin{tabular}{|c|c|c|c|c|c|c|}
\hline Treatments & Germination \% & $\begin{array}{c}\text { Rel. } \\
\text { germination } \%\end{array}$ & $\begin{array}{l}\text { Germination } \\
\text { index }\end{array}$ & $\begin{array}{l}\text { Root length } \\
\text { (cm) }\end{array}$ & $\begin{array}{c}\text { Rel. root } \\
\text { length }(\mathrm{cm})\end{array}$ & $\begin{array}{l}\text { Weight } \\
\text { gained }\end{array}$ \\
\hline distilled water & $65 \mathrm{bc}$ & $100 \mathrm{abc}$ & $100 a$ & $1.455 \mathrm{abc}$ & $100 \mathrm{ab}$ & $0.310 \mathrm{~b}$ \\
\hline $50 \% \mathrm{C} 1$ & $70 \mathrm{abc}$ & $109.5 \mathrm{abc}$ & $135.5 \mathrm{a}$ & $1.865 \mathrm{a}$ & $135.5 \mathrm{a}$ & $0.53 \mathrm{ab}$ \\
\hline $50 \% \mathrm{C} 1+\mathrm{BM}$ & $75 \mathrm{abc}$ & $114.5 \mathrm{abc}$ & $83 a$ & $0.8850 \mathrm{c}$ & $67 b$ & $0.335 b$ \\
\hline $50 \% \mathrm{C} 1+\mathrm{BMP}$ & $85 \mathrm{ab}$ & $131 \mathrm{ab}$ & $118 \mathrm{a}$ & $1.295 \mathrm{abc}$ & $90.5 \mathrm{ab}$ & $0.580 \mathrm{ab}$ \\
\hline $100 \% \mathrm{C} 1$ & $70 \mathrm{abc}$ & $107 \mathrm{abc}$ & $144 \mathrm{a}$ & $1.895 \mathrm{a}$ & $133 a b$ & $0.475 b$ \\
\hline $100 \% \mathrm{C} 1+\mathrm{BM}$ & $85 a b$ & $132 \mathrm{ab}$ & $99 a$ & $1.090 \mathrm{bc}$ & $85 \mathrm{ab}$ & $0.420 \mathrm{~b}$ \\
\hline $100 \% \mathrm{C} 1+\mathrm{BMP}$ & $65 \mathrm{bc}$ & $100 \mathrm{bc}$ & $77 \mathrm{a}$ & $1.070 \mathrm{bc}$ & $77 \mathrm{ab}$ & $0.320 \mathrm{~b}$ \\
\hline $50 \% C 2$ & $65 \mathrm{bc}$ & $103.5 \mathrm{abc}$ & $111.5 \mathrm{a}$ & $1.615 \mathrm{abc}$ & $112 \mathrm{ab}$ & $0.475 b$ \\
\hline $50 \% C 2+B M$ & $60 \mathrm{c}$ & $93 c$ & $83.5 \mathrm{a}$ & $1.300 \mathrm{abc}$ & $90 \mathrm{ab}$ & $0.340 \mathrm{~b}$ \\
\hline $50 \% \mathrm{C} 2+\mathrm{BMP}$ & $80 \mathrm{abc}$ & $123.5 \mathrm{abc}$ & $117 \mathrm{a}$ & $1.350 \mathrm{abc}$ & $97 \mathrm{ab}$ & $0.325 b$ \\
\hline $100 \% \mathrm{C} 2$ & $75 a b c$ & $118 a b c$ & $142.5 a$ & $1.685 \mathrm{ab}$ & 111.5ab & $0.83 a$ \\
\hline $100 \% \mathrm{C} 2+\mathrm{BM}$ & $90 \mathrm{a}$ & $139.5 a$ & $140 \mathrm{a}$ & $1.440 \mathrm{abc}$ & $101.5 \mathrm{ab}$ & $0.490 \mathrm{~b}$ \\
\hline $100 \% \mathrm{C} 2+\mathrm{BMP}$ & $75 \mathrm{abc}$ & $115.5 \mathrm{abc}$ & $85 a$ & $1.035 \mathrm{bc}$ & $74 \mathrm{ab}$ & $0.270 \mathrm{~b}$ \\
\hline
\end{tabular}

R.G $\%=\underline{\text { No of seeds germinated in compost extract }} \times 100$

No of seeds germinated in control

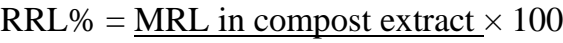

\section{RESULTS AND DISCUSSION}

Table 1: Germination Analysis Of Maize Seeds Using Compost Extracts

Where $\mathbf{C 1}=\mathrm{PM}+\mathrm{RB}+\mathrm{GL}, \mathbf{C 1}+\mathbf{B M}=\mathrm{PM}+\mathrm{RB}+\mathrm{GL}+\mathrm{BM}, \mathbf{C 1}+\mathbf{B M P}=\mathrm{PM}+\mathrm{RB}+\mathrm{GL}+\mathrm{BMP}$

$$
\mathbf{C 2}=\mathrm{PM}+\mathrm{SD}+\mathrm{GL}, \mathbf{C 2}+\mathbf{B M}=\mathrm{PM}+\mathrm{SD}+\mathrm{GL}+\mathrm{BM}, \mathbf{C 2}+\mathbf{B M P}=\mathrm{PM}+\mathrm{SD}+\mathrm{GL}+\mathrm{BMP}
$$

Where BMP = Bone meal post compost fortification. 
It was observed that at $100 \%$ concentration of the compost extract where co-composting fortification was done had better germination than where bone meal was not added at all and where post composting fortification was done. This may be due to the fact that addition of bone meal at the onset of composting resulted into adequate supply of phosphorus during composting which made it cure better and promoted good germination. While the other form of fortification had no significant difference from when it wasn't fortified at all with phosphorus source. (Andreas baumgarten 2004).

When the actual compost extract concentration (100\%) was used, it was observed that where bone meal was not added at all, higher germination index was recorded than when bone meal was added at the onset of composting and when it was added after maturation of the compost. This may be due to the fact that excess phosphorus supplied by bone meal addition can inhibit plant growth i.e phytotoxicity. This was reported by Tiquia (1996) that decrease in yield and inhibition of seed germination can set in when phosphorus and any other nutrient is excessive in compost. Zucconi (1990) reported that, germination index is a measure of compost phytotoxicity. A germination index lower than 60 is regarded to be highly phytotoxic (Emino and Warman 2004).

On the other hand when $50 \%$ concentration of compost extract was used for germination test, it was observed thatwhere post composting fortification was done, the compost had better germination index than when bone meal was not added at all and when it was added at the onset of composting. This may be due to the fact that the extra phosphorus added gave the compost optimum nutrient quality that is needed for maize germination. A better mean root length, root elongation and weight gained was observed where bone meal was not added at all compared to when it was added before and after composting. This may be as a result of excess phosphorus in the extract; excess phosphorus produces contaminant such as cadmium and fluorine (New Zealand year book, 1996). It was also reported by Sinclair, 1999 that fluorine interacts strongly with aluminium and aluminium toxicity inhibits plant growth. When diluted extract was used, a good result was observed when bone meal was added after composting. This revealed that phosphorus had effect at a lesser concentration of the compost extract. Therefore we can assume that phosphorus in the co-composted compost was already used up by microbes in the pile before compost maturation.

\section{CONCLUSION AND RECOMMENDATION}

In terms of days to maturation of compost, rice bran-based compost reaches maturity(curing) faster than sawdust-based. Rice bran-based compost cures faster without fortification and sawdust-based compost cures faster with fortification. Further conclusion is that fortification at the onset of composting promotes plant growth, not fortifying at all reduces the risk of phytotoxicity and fortifying after maturation increases the chance of phytotoxicity.

In order to enhance plant growth with the use of compost-type biofertilizer, it is highy recommended that the compost should be fortified at the onset of composting (co-composting), but in a situation whereby post composting fortification should be done, synthetic phosphorus source may be used instead of bio solids (Bone meal). In order to reduce farmer's risk of phytotoxicity occurrence, it is recommended that the farmer should ensure that the compost is completely cured before application and the farmer should fortify at the onset of composting.

\section{ACKNOWLEDGMENT}

The Authors of this paper would like to acknowledge Department of Crop and Environmental Protection of Ladoke Akintola University of Technology, Ogbomoso Oyo State Nigeria for providing the platform for this research work. Special appreciation goes to Prof. G. O Adesina and the entire staff of the department.

\section{REFERENCES}

1. Baumgarten A. Spiegel H. (2004). Phytotoxicity (Plant tolerance) Agency for Health and Food Safety, Vienna.

2. Brewer L. J and Sullivan D. M (2003); Maturity and Stability Evaluation of Composted Yard Trimmings. Department of Crop and Soil Science, Oregon State University, Corvallis, Oregon.

3. Emino E. R and Warman P. (2013); Biological Assay for compost Quality. Article in compost science and utilization.

4. Michelle le strange (2012) Recognizing herbicide phytotoxicity, master gardners newspaper article page 2.

5. New Zealand year book (1996). Effect of phosphorus in the environment, pg 27.

6. Tiquia S . M., Tam. N . F . Y., Hodgkiss I . J. (1996). Effect of composting on phytotoxicity of spent pig manure saw dust litter. Environmental Pollution. 93, 249-256. 
7. Zucconi F. and de Bertoldi M. (1987). Compost specification for the production and characterization of compost from municipal solid waste. Bertoldi, M.de et al. (Eds.), Compost: production, quality and use. Elsevier, Barking, pp. 30-50.

8. Zucconi F., Pera A., Forte M. and de Bertoldi M. (1981). Evaluating toxicity of immature compost. Biocycle $22,54-57$. 